This article was downloaded by: [New York University]

On: 03 May 2015, At: 00:06

Publisher: Routledge

Informa Ltd Registered in England and Wales Registered Number: 1072954

Registered office: Mortimer House, 37-41 Mortimer Street, London W1T

3J H, UK

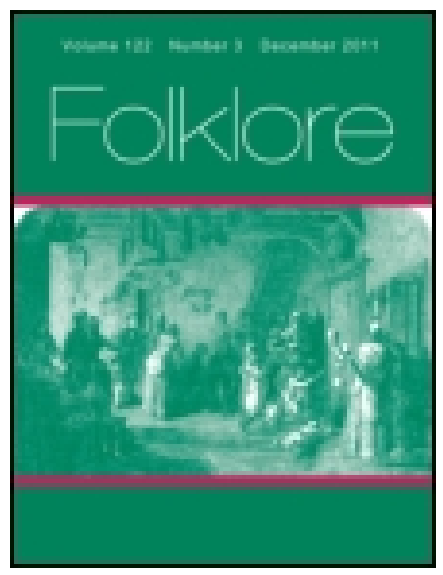

\title{
Folklore
}

Publication details, including instructions for authors and subscription information:

http:// www. tandfonline.com/loi/ rfol20

\section{Folklore and History in Ireland.}

D. H. Moutray Read

Published online: 01 Feb 2012.

To cite this article: D. H. Moutray Read (1918) Folklore and History in Ireland., Folklore, 29:4, 281-304, DOI: 10.1080/0015587X.1918.9719068

To link to this article: http:// dx. doi. org/ 10.1080/0015587X.1918.9719068

\section{PLEASE SCROLL DOWN FOR ARTICLE}

Taylor \& Francis makes every effort to ensure the accuracy of all the information (the "Content") contained in the publications on our platform. However, Taylor \& Francis, our agents, and our licensors make no representations or warranties whatsoever as to the accuracy, completeness, or suitability for any purpose of the Content. Any opinions and views expressed in this publication are the opinions and views of the authors, and are not the views of or endorsed by Taylor \& Francis. The accuracy of the Content should not be relied upon and should be independently verified with primary sources of information. Taylor and Francis shall not be liable for any losses, actions, claims, proceedings, demands, costs, expenses, damages, and other liabilities whatsoever or howsoever caused arising directly or indirectly in connection with, in relation to or arising out of the use of the Content.

This article may be used for research, teaching, and private study purposes. Any substantial or systematic reproduction, redistribution, reselling, loan, sub-licensing, systematic supply, or distribution in any form to anyone is 
expressly forbidden. Terms $\&$ Conditions of access and use can be found at http://www.tandfonline.com/page/terms-and-conditions 


\section{FOLKLORE AND HISTORY IN IRELAND.}

HY D. H. MOUTRAY RRAII.

(Read before the Society, Fune 19th, 1918.)

If Ireland was but an island in the South Pacific, it is safe to assert that it would be the happy hunting ground of the ethnographer, anthropologist, and folklorist. Having the fortune to be one of the islands of the British Archaepelago it is therefore supposed to be known, and, consequently, to a large extent is an undiscovered region. So greatly was this the case that my previous paper on Irish folklore came to be written because it had been asserted that there were practically no Calendar Customs in Ireland. Some work has been done since then, with the result that Miss Burne, now editor-in-chief of the new "Brand," after looking through the collected matter for May, commented that the Irish Calendar Customs for that month were more fresh, more alive, and more complete, than from any other part of the kingdom.

But if much has been done, far more remains for the doing, and the matter with which the bulk of my paper deals to-day is one that has many gaps to fill, as may be judged by the fact that on looking through the Calendar Customs "slips" I could find practically none but my own work that touched at all on the subject.

Taking Ireland, then, as in many respects a folklorically undiscovered country, let us try to apply to its study some of the maxims laid down by Dr. Marret in his last presidential address. To get the folklore of a country into focus something more is needed than a pile of orderly MS. 
"slips." If we were dealing with a far off island we should enquire into its geographical and topographical conditions, its history, religious system or systems, and social organisation in general. They are equally of importance as aids to the study of one of the British Isles. Yet the very first point-geographical control-is usually ignored, though the effect of geographical conditions on the story of Ireland, and consequently on its folklore, has been deep and far reaching.

Consider for a moment Ireland's position on a map. It is not only an island, that is to say cut away from the mainland, the centres of life and cultural movements, but it is an island separated from these by another and a larger island. Obviously the first "injustice to Ireland " was that she was not placed by Nature in the situation occupied by her dominating sister. Such interference with a country's "place in the sun" cannot be rectified by centuries of protest and invective. Furthermore, climatic conditions serve to exaggerate the evil, for those very portions of the island furthest removed from influences that make for progress, by geographical influences are subjected to a more enervating climate than the districts more favourably placed. Therefore both climate and situation are factors that should be taken into careful consideration when examining the radical causation of Irish problems.

Nor is this all. If Ireland was cut off from the continental tide of cultural movement she was by that very isolation protected from early interference, and was able at one time to develop a degree of civilisation of her own far ahead of her neighbours. Yet this apparently beneficial factor has, in truth, been her undoing. There was no stimulus of conflict. She never had the steadying if drastic treatment of Roman subjugation to imbue a sense of discipline, to incite a recognition of the need and values of organisation, and to lay the foundations of national 
unity. She never, in short, realised that in this world "no. man liveth to himself," so that in the twentieth century she can still be torn and racked by a faction whose very name betrays incompetence to achieve in the ultimate - Sinn Fein-ourselves alone.

It is extraordinarily evident, once critical attention is drawn to the point, how that insidious "ourselves alone" pervades Irish history and permeates Irish thought. Ireland has suffered terribly. But her sufferings are not peculiar in the history of mankind. The horrors of the Elizabethan wars, the Ulster rebellion, the Cromwellian campaign, do not stand out as solitary instances of brutal doings. Their counterpart is to be found in other places. The sack of Drogheda was a small thing compared with the sack of Magdeburg. The massacres-be they of Irish by English, English by Irish, loyalists by rebels, or rebels by royalists, are not the only, or by any means the worst massacres the world has known. Ireland, with too much of the "inward-turning eye" talks, and what is worse thinks, as though they were. But Scotland passed through days as black, wars as destructive, legislation as crippling, as any Ireland has experienced-yet Scotland does not pose as a "most distressful country." It is evident that we must go deeper than surface matters to find a reason for this difference. Race does not explain it. Racially the two countries are very nearly akin. If Scotch settlers were brought to Ulster in the sixteenth and seventeenth centuries Irish invaders had settled in Scotland in the third. The folklore of the Highlands and Islands has more in common with Irish folklore than any other; in fact, Joyce refers the student to it for knowledge of primitive Irish customs and beliefs. Am I wrong then in suggesting that the determining factor has been geographical control?

History is a longer and terribly complex matter to deal with. It is becoming more and more evident that the study of folklore and history are interdependent. If folk. 


\section{Folklore and History in Freland.}

lore supplies footnotes to history it, in turn, enables the student to make a true digest of folklore. If scientific rather than sentimental treatment were accorded Ireland we would be facing a very different set of problems in that island. The Americans have recently discovered that much of the misunderstanding and prejudice that existed in the United States as regards Great Britain was due to the faulty teaching of history, and the one-sided and frequently erroneous text-books employed in the education of the young. If this is true about America it is a thousand times more so in the case of Ireland. Unfortunately not history but confirmative argument on the side of each disputant has been too much the desideratum, let the politics be what blend soever of red, yellow, or blue, and so careful a student as Lecky will be disregarded in favour of a more prejudiced and infinitely more ignorant writer who wears the coloured label they themselves affect. One party is fed with tales of terror rooted in the misgovernment of England; another is fired with horrific details of the misdoings of rebellious Ireland. And a vivid imagination is the gift of the land.

It is true that History provides but little more than an articulated skeleton at best; Literature tricks it out with raiment; but it is to Anthropology that the student of the future will look for provision of flesh and blood to complete the picture. For folklore reflects history. It is the record of the life of the people. It is affected by contemporary events, even by the fluctuating politics of the day, in just so great or so little degree as the folk themselves are affected. Where politics have a dominating influence on life, as unhappily has been-and is-the case in Ireland, politics mould, mar or make folklore. The lore may be entirely diverse from the political event that gave it inception. As a contemporary instance may I remind you of the sale of primroses in Dublin on April 19th to which I referred in my last paper. The orange lilies of the Twelfth of July do not come into quite the same category; they have 
retained their significance, the reason for their use is generally known, and they are the memento of an event rather than a selected symbol for an ideal.

To some extent her geographical position and its consequences were doubtless the reason why Ireland, though she had a plethora of saints-with a few of more than local importance-produced no great national leaders, at least none of more than local importance. Even Lecky seems to have found no clue, at least he suggests none, to the problem why Ireland with her higher culture never developed a Clovis or an Alfred. Yet she had more centuries to achieve this than France or England took in the doing. With conditions primarily more favourable she achieved less. It would seem as though the Irish were themselves cognisant of this failure, or was jealousy the only reason why they turned so often to others than those of their own blood for leadership, and offered the kingdom to an Edward Bruce, a Philip of Spain, or a Louis of France? Yet that Irishmen make unrivalled leaders the British Empire has cause to know. I yield to none in admiration of my countrymen. Where would the British Empire be to-day had we not had a Wellington and a Roberts ?

But lacking the leaven of organisation bequeathed by Imperial Rome to her conquered territories, the Irish social system was largely deficient in those elements that make for consolidation. The bond of kindred only was not sufficient to withstand the onslaughts of the Danish pirates. In Anglo-Saxon England it gave way to institutions making better for general unity of purpose and protection. In Gaelic Ireland this was not the case, which probably explains why Ireland ouffered more lasting damage at the hands of the sea rovers. ${ }^{1}$

It may make my ergument clearer if I summarine briefly the eccount of the Irish mocial atructure given by Joyce in his Secial History of Iroland,

The country was divided into five provinces, each comprised aumber of tribes subdivided into clans, and these were again divided into famillen. Joyce 
The Irish are not racially homogeneous. To judge by legends Irish Princes had a preference for seeking brides from alien countries. Trade and pillage brought adventurers from other lands to the Irish shore. For the most part the coast lands only were affected by these intruders, and especially the towns. Despite their many misdoings in the land Ireland has to thank the old pirates from the Baltic and North Seas for the foundation of some of her finest cities. Dublin, Cork, Limerick and Waterford, for example, were originally settlements of Danes,-the last of whom, according to tradition, embarked from the Rock of Dunmaul in the Giant's Causeway, where oral history states that "in the olden times" all the rents of Ireland were paid. If all the Danes did leave, a tradition history does not entirely

rejects the word "Sept" as modern and incorrect. The political unit was the tribe (Tuath). A combination of two, three or more tribes was a Mor-Tuath. The family consisted of all the descendants of any living couple. The clan (Clann meaning children) comprised several families, the nearlyielated descendants from a common ancestor. The Tuath consisted of a number of clans supposed to be descended from a common ancestor. [The nomenclature is not up to date in accordance with the Ilandbook, but I summarise Joyce.] Besides blood relationship there was relationship by adoption, either of an individual-with the consent of a representative family circle-or of a group, that is to say a small tribe might be adopted by a larger for parpose of common defence, etc. There was further what Joyce calls religiou relationship, i.e. gossipred; and also fosterage-considered a most sacred tie. There were four degrees of kings-over-king, king of the province, king of the mor.tuath, king of the tuath-small wonder it is said that every Irishman claims king for forebear! Next in rank came the nobles, large owners of property, some of it land. Helow these were the non-noble freemen, rent-paying, with property in cattle. The fourth grade consisted of freemen with little or no property. Finally came those who were not free horn. As regards the division of land each tribe held a definite district, and each clan its sub.district. Individual tenure: the king held a portion as mensal land for life, this descended by tanistry. Frivate property in land descended by inheritance, and included the homestead and ground held by every free member. Thirdly, there were tenanta. Tribe lands-arablewere held by clans in subdivision from the tribe and liable to gavelkind. Pastures were common-land. Sometimes land was held by a family, but not hy any individual member. 
corroborate, other encroaching strangers ere long took their place. Apart from the intermixture of Danish, Norman, and English immigrants, the Plantation-or rather plantations-of Ulster were not the only official settlements of folk of alien blood in the land. King's County and Qucen's County were "planted " among others; it is said that Cromwellian soldiers settled in Tipperary, which has been given as the explanation of the fine physique of Tipperary men, so different from the small dark type found in Longford for instance; German Palatines were brought over at the commencement of the eighteenth century to Wexford, Limerick, and Kerry ; there was a considerable influx of French Huguenots after the Revocation of the Edict of Nantès. Tradition has it that the glossy black hair seen in the south and the west are the heritage bequeathed to their descendants by survivors of the Spanish Armada. Either more survived than history wots of, or the survivors were unduly prolific. Actually Spanish blood must have been more frequently introduced through trade connections than by accident of war.

The Anglo-Norman invaders brought with them their own Feudal System, which, diametrically opposed as it was to the indigenous system, might have done for Ireland what Roman methods did for England, had the whole island been brought into subjection under it. This was not done. The Norman adventurers who settled in Ireland, removed from central constraint became, notoriously, "more Irish than the Irish," and succeeding efforts to superimpose English methods, laws, customs, and organisation were a continual seesaw between suppression and concession, the one raising hatred, the other contempta dangerous combination. The conditions that made for an absence of cohesion among the Irish themselves in a measure operated to hinder amalgamation of native and foreign elements in the population. The latter remained distinct or were submerged. And when to 
these natural factors artificial ones were added a fine hot-bed of trouble was well in preparation, and the resultant clash of cultures, intermittently intensified, has continued to this day.

It is to one section of the transplanted customs I wish to draw your attention to-day, for though the pages of Folklore have record of Irish legends, charms, May customs and Hollontide doings, there is no reference to the purely urban customs connected with civic life in Ireland. Naturally these have much in common with English municipal customs, yet if it were only to mark those very similarities, or to note digressions from the parent type, it seems to me they would be worth consideration.

So far as municipal organisation and government were concerned Irish towns were modelled upon the examples of English towns. It was, you will remember, customary in mediaeval days, when a town obtained a charter, to borrow the experience of an older town and copy the successful features of its administration and privileges. It became what is known as the mother town or city. So when the Plantagenet kings, as bribes or rewards, began to bestow rights of local self-government on their Irish towns, Bristol was the city most frequently selected as prototype, and her charters were adopted as the model for those granted to the greater number of Irish municipal institutions. The daughter town not only copied the administrative of her mother town, but also would appeal to the latter for solution of legal or civic difficulties. There are frequent references, for instance, of appeals by Dublin to Bristol for such aid. The chief magistrate of Irish municipalities appears for a long time to have been more often termed the Sovereign than the Mayor of the town. Wesley, during his visit to Belfast, refers to the Sovereign not the Mayor, even in his day. ${ }^{1}$

1 There are many tempting premises in commection with the vord, but, so far, I have not been able to make gookl any that suggested themselves to ine, 


\section{Folklore and History in Treland.}

The dates for the election and swearing in of the town officers varied. As a rule the new Mayor took office on Michaelmas Day. There is more divergence of dates for their election. Midsummer claims most, either the Day or the Monday after it, as at Kilkenny and Carrickfergus. Dublin's Lord Mayor and Aldermen were elected in April, the Portreive on St. Matthew's Day-to take office on St. Canice's Day. Galway's Mayor and Bailiffs were chosen at the "Short Council" on the last day of July. Waterford's Mayor was chosen by the Council on the Monday after the Feast of the Visitation of the Blessed Virgin Mary, and took his " corporal oath on the Holy Evangelists yearly on the Feast of St. Michael the Archangel."

The growth of the towns is in itself a proof of the need that existed for outside stimulus. They were the outposts of invading culture, and the antagonism between town and country is a factor to be noted. While country districts clung undisturbed for the most part to the old ways, the towns ostentatiously followed the new. The place-name Irishtown preserves the memory of legislation that restricted intercourse between the English, or Anglicised citizens, and the "mere," that is the pure or unmixed, Irish. 1 These, for fear of treachery, were, as a rule, debarred from holding any civic post, and business with them had in certain cases to be conducted outside the walls. Even marriage with an Irishwoman was enough in some places to bring a loss of privileges to the adventurous husband. Cork was "so compassed with rebellious Neighbours," Fynes Moryson reported in 1603 , that the citizens " of old

or were suggested by others. The N.E.D. gives sovereign as an obsolete name for the chief magistrate, more general in Irelund than in England.

\footnotetext{
"Spencer used the tern "meer Irish" to denote the pure bred Irish. If also wrote of "meer English" in the same sense, but the "meer Irish" has been quoted as an instance of English contempl, and used to embitter feeling between the two countries.
} 
not daring to marry their Daughters to them, the custom grew and continues to this Day, that by mutual marriages one with another all the citizens are of kin in some degrec of Affinity." In this connection it is not without interest to note that the office of major became at one period hereditary in Cork.

Given these conditions it is not surprising to find continual feuds between the urban and rural population, such as that between Waterford city and the O'Driscols. "Yet this," according to an old MS. in the library of Trinity College, Dublin, "did not hinder the mayor and a chivalrous party of his citizens from going by sea on Christmas eve (A.D. 1453) well armed," be it noted, "to Baltimore, and presenting themselves to O'Driscol and his family at their Christmas dinner in the hall. They soon relieved them of their terrors, by telling them they had come, not to injure them but to carol and to dance. And having enjoyed his hospitality, they brought O'Driscol and his family back with them to Waterford, to partake of the city festivities, and to dance on St. Stephen's Day." 1

On the face of things it would seem probable that an incident in connection with such local warfare gave rise to the custom of blocking the Irish, or West Gate of Carrickfergus on Christmas Eve with carts, cars, gates, planks, and so forth, collected by young men and boys. There is, however, doubt as to the early origin of the practice, for M'Skimmin declares some of the older in. habitants denied knowledge of it in their young days, and he mentions a "vague" tradition that it arose from Protestants having barred out Roman Catholics. It does not appear very likely though that an event of this kind should not be remembered other than vaguely if it occurred in the lifetime of living man, and the reason is just such a reason as, knowing no other, an Antrim man would proffer. The town's historian specifically states that there was no

1 Prendergast, Crom. Set., p. 297. 
animosity in those days between members of the rival churches.

However this may be, the charter granted to Killmallock in 1482 sets forth that: "The King considering the many losses, hazards, burnings and other grievances which the town of Killmahalloke and his liege inhabitants thereof had sustained from his Irish enemies and English rebels... for the better government and defence of the town... grants a license to the Burgesses and their successors yearly to elect from among themselves, on the Monday after the 29th September, with the consent of twelve of the better and chief Burgesses, or the major part of them, one of the Burgesses to be Sovereign." Dingle, again, "for the faithful services of the inhabitants, done from time to time to the King and his progenitors" was made a "free town and borough corporate with a sovereign elected yearly on St. James's day, to enter on his office the Michaelmas following. To have a sword and mace carried before him... with a liberty of two English miles, round the parish church."

From their beginning the towns were built and organised for purposes of defence. According to the "Statuts of Kilkenny" it was ruled "That the Burrow Towns be made sure and fast and the Customs yerely be well bestowed upon the Walls and Ditches of the said towns on their proper costs, six Days in the month of March any yere from henseforward to repaire and make fast their Walls and Ditches." Not a few towns won their charters by giving military aid beyond their own vicinage to the Lords Deputy-for all maintained their trained forces. Dungarvan citizens-the town was incorporated about $1463-$ obtained a charter "for their fidelity to the crown during the Rebellion in Queen Elizabeth's time." The town's privileges were renewed in the charter that "changed the government of the Portreive into that of a sovereign, Recorder, and twelve Brethren, who were to be yearly 
chosen five days after the Feast of St. Peter. The Admiralty of the harbour was granted to the Sovereign with the same extent of power as the Mayor of Bristol had."

The ceremonies consequent on the possession of Admiralty rights by Mayors of seaport towns are by no means the least interesting of Irish municipal customs. These, mediaeval observances that have lingered on to our day, have a dramatic touch about them certain to appeal to the Irish temperament. What is more characteristically Irish even is the uncertainty of record regarding such mere details as dates I To a certain extent the day must depend upon the tide, the lowest tides obviously being a desideratum.

The charter granted to Cork city by Edward IV. gives the franchises of the city seawards as including all strands " in and to which the sea ebbs and flows, in length and breadth within the aforesaid two points, called Rewrawne and Renowdran." "We have," says Gibson, " neither of these "aforesaid two points' marked on any ancient or modern map of Cork ... but conclude it is between these two points outside the harbour's mouth where the Mayor of Cork throws the Dart." He quotes a local paper, unnamed and undated, which describes how, "having reached the nocessary point at the Harbour's mouth, the Mayor put on his robes, and the Collar of SS, took the arrow, which was about a yard and a half in length with a heavy iron barbed head, and proceeding to the bow of the vessel, accompanied by the entire of the party (sic), threw it into the water amid a loud cheer."

Cf. similar customs at Sandwich in connection with Canute's grant in 1031. Also at Fordwich, and the fief held by Yorkshire constable by shooting an arrow annually in to the sea.

Very similar was the Limerick custom. Lenihan quotes from White's MSS. "The Order of Franchises of Limerick ": "On Thursday, the Ioth of September, the Mayor, Sheriffs, and rest of the Corporation, in the King's yachts, went 
lown the river, in order to assert and make good his right of being admiral of the river Shannon. On Thursday, the 12th of September (sic), the Mayor held a Court of Admiralty on the island of Inis Scattery, and on Friday, the I 3 th, he sailed to the mouth of the Shannon, where, between the heads, he threw a dart into the sea to point out the limits of his jurisdiction; at the same time it happened that a sloop of war entered the river, whom the Mayor compelled to lower her colours and her foretopsail in acknowledgement of his Power of Admiralty in said river Shannon. The Mayor and Corporation returned to Limerick on Saturday, the 14th, by ringing of bells, etc."

In connection with this there is a feature of the famous Claddagh village that is worth repeating. Hardiman, in his History of Galway, in a long footnote on the Claddagh community and customs, mentions the following: "This colony from time immemorial has been ruled by one of their own body, periodically elected, who somewhat resembles the Brughaid or head villager of ancient times, when every clan resided in its hereditary canton. This individual, who is dignified with the title of mayor, in imitation of the head municipal officer of the town, regulates the community according to their own peculiar laws and customs, and settles all their disputes. Ifis decisions are so decisive, and so much respected, that the parties are seldom known to carry their differences before a legal tribunal, or to trouble the civil magistrates. They neither understand nor trouble themselves about politics, consequently in the most turbulent times their loyalty has never been questioned, and they are exempt from all government taxes. Their mayor is no way distinguished from any of the other villagers, except that his boat is generally decorated with a white sail, and may be seen at sea (at which time he acts as admiral) with colours flying at the mast-head gliding through their fleet with some appearance of authority." 
This is all the more interesting as I do not think the mayor of Galway had any admiralty rights, at least Hardiman mentions no such custom as those performed by the mayor of the senior city of Limerick.

The Dublin ceremony smacked more of the Mayor and less of the Admiral. Every member of the twenty.five city companies, "prepared as for a jubilee" to accompany the Lord Mayor on his tri-annual tour round " the fringes." Dublin claimed to have "the most magnificent of showy processions ... except those of Rome," and visitors from England would come to witness the sight. When the procession reached the strand the Lord Mayor rode out into the sea as far as his horse could find foothold, and between the Black Rock and the Lighthouse hurled a lance out into the water. Where it struck made the limits of municipal jurisdiction for the next threc years.

Different writers have suggested a variety of meanings and origins for these customs, ranging from Druidical magic rites to the Venetian marriage of the Adriatic! For my part I do not see that any such abstruse explanation is necessary to seek. To measure by a bowshot or a spear's cast is no new thing, nor need one smell magical rites in the doing. It was a practical act. Magic may accumulate round it, as for that matter it may around anything. But the act gave rise to the magic, not the magic to the act, and the act in the first instance was purely utilitarian. If the Danes measured in this fashion the custom may well enough have come down from the days when their long barques lay in the fair harbours of Ireland, and Danish settlements arose where the Irish cities stand to-day; but as a mayorial custom it is nothing more than a picturesque survival of primitive methods, a symbol to be classed with the thrusting of the Lord Mayor's sword through a hole in the wall when, during the perambulation of Dublin, he skirted the Farl of Meath's liberties-or the arrying of a silver oar by the Bailiffs of Carrickfergus, 
without which sign of jurisdiction they could arrest for. recovery of debt no sailor or other person in any vessel.

From these dignified proceedings to civic drinking bouts may seem a sad falling off-though a feast, or a drinking, would be, after all, but the natural end-in Ireland-of any ceremonial display, and I have one or two notes on this point which may at least amuse you.

James II. annulled the Dublin charters, and as he did elsewhere, dismissed all except Jacobite Aldermen. The deposed Aldermen, however, continued to assemble privately at an alehouse in Skinner's Alley. There they elected their own Lord Mayor and officers, until after the Battle of the Boyne they were reinstated in office by William III. From this originated the name of the first Orange Association, which was called the Association of the Aldermen of Skinner's Alley. According to Barrington, "A lord-mayor was annually appointed; and regularity and decorum ... always prevailed until, at least, towards the conclusion of the meetings... King William's bust being placed in the centre of the table.... Their charterdish was sheeps trotters (in allusion to King James's running away from Dublin), rum punch in blue jugs, whiskey punch in white ones, and porter in its pewter.... The real business began by a general chorus of "God Save the King!" The "lord-mayor" then gave the charter-toast, "always given with nine times nine." On July I "Every man unbuttoned the knees of his breeches and drank the toast on his bare joints" :

"The glorious,-pious, -and immortal memory of the great and good King William-not forgetting Oliver Cromwell, who assisted in redeeming us from popery, slavery, arbitrary power, brass-money, and wooden shoes. May we never want a Williamite to kick the... of a Jacobite 1 and a... for the Bishop of Cork 1 And he that won't drink this whether he be priest, bishop, deacon, bellows-blower, grave-digger, or any other of the fraternity 
of the clergy; may a north wind blow him to the south, and a west wind blow him to the east I May he have a dark night - a lee shore-a rank storm-and a leaky vessel to carry him over the river Styx I May the dog Cerberus make a meal of his rump and Pluto a snuff-box of his scull! and may the devil jump down his throat with a red hot harrow, with every pin tear out a gut, and blow him with a clean carcase to hell! Amen!"

According to Charles Kingsley the Irish conception of a Saint was an individual with great cursing powers. The gift has not died out of our land.

Those were the days when an Orange Corporation had the pedestal of King William's equestrian statue in College Green painted orange and blue, and decked it annually on the anniversary of the Boyne with orange lilies and ribbon, while a bow of green was placed beneath the uplifted foot of the horse.

Drinking was not confined to one city or faction, it would appear to have been a regular municipal accomplishment, nor is it one peculiar to Ireland. Among the old city records of Waterford is this naive entry :

It was decreed by the Mayor and Council in 1496 that "whensoever it shall fortune any of the VI Sondayes of the Lenten in which, by the old and laudable custome of the citie the drinking is holde and kepte, to fall voide by the death of any person, or otherwise, than of the Maire for the tyme being, have none of the same drynking dayes the Council shall assyne the same day to the Maire,", and in I 503 it was added that no one should be allowed to coine to these Sunday "drinkings" except members of the Council. At Dingle, an old writer quoted in the Kilkenny Archaelogical Society's Transactions, describes how, "Upon the Sunday the Sovercign cometh into the Church with his Serjeant before him, and the Sheriffs and others of the Towne accompany him, and then they kneele downe every matn by himself privately to make his prayers. After this 
they rise and go out of the church againe to drinke, which, being done they returne againe into the church and then the minister beginneth prayers." Obviously something other than ecclesiastical spiritual assistance was needed to bring the worthy Corporation, as by law demanded, to the services of the Established Church! In the north we get a soberer touch. At Carrickfergus not only were the freemen obliged to attend the Mayor to church on Sunday, but at each Quarter Sessions enquiry was made anent such attendance, and if the aldermen and burgesses "ordained to have and wear gowns" duly wore them "upon every Sunday and Holydays in the Church and the Court."

Sundays were not the only Calendar dates to be observed by Irish corporations, and as one of the sub-editors of the new "Brand" I wish to draw your attenton to these locill observances, and enlist your interest and assistance. I merely mention the following as examples of what may be found-and when found made a "slip" of I

The Festival of St. George was an important thing once in Dublin, and Ledwich notes that on St. George's Day there was a great cavalcade in Kilkenny, "when the Lords rode in their places." This is interesting, taken in conjunction with the town's armed forces, for " in 1479 , a military society, called the fraternity of St. George, was instituted for the defence of the counties... [Dublin, Kildare, Meath and Louth] and consisted of thirteen principal men, resident in those countics, who all met in Dublin on St. Gcorge's day in each year, and chose from amongst themselves a captain or leader." The socicly ceased to exist in 1494 " not having been found to answer the designed end."

A custom that arose out of an incident in party feucis took place in Jublin on Corpus Christi Day. The Lord Mayor, as chief magistrate, had to walk barefoot through the city "in open procession before the sacrament" in expiation of the city's " execrable offence "--as the Legate 
put it-of a man having been killed in the chancel of St. Patrick's during a fight between the followers of Ormonde and Kildare. But the custom cannot have been of long continuance, for one can hardly picture a Protestant Lord Mayor submitting to it.

Hardiman mentions a Claddagh custom at Midsummer: "The Nativity of St. John the Baptist," he says, "they celebrate by a very peculiar kind of pageantry. On the evening of that day the young and old assemble at the head of that village; and thcir Mayor, whose orders are decisive, adjusts the rank, order, and precedent of this curious procession. They then set out, headed by a band of music, and march with loud and continued Huzzas and acclamations of joy, accompanied by crowds of people, through the principal streets and suburbs of the Town: the young men all uniformly arrayed in short white jackets, with silken sashes, their hats ornamented with flowers, and upwards of sixty or seventy of the number bearing long poles and standards with suitablo devices, which are in general emblematic of their profession. To heighten the merriment of this festive scene, two of the stoutest disguised in masks, and entirely covered with parti-coloured rags, as 'merrymen' with many antic tricks and gambols, make way for the remainder. In the course of their progress, they stop with loud cheering and salutations opposite the houses of the principal inhabitants, from whom they generally receive money on the occasion. Having at length regained their village, they assembled in groups, dancing round, and sometimes leaping and running through their bonefires, never forgetting to bring home part of the fire, which they consider sacred; and thus the night ends as the day began, in one continued scene of mirth and rejoicing."

A curious feature in Irish urban history is the connection of the mayors with bulls and bull-baiting. The last public act of the Mayor of Carrickfergus was to go to Church in 
procession. Then to the Castle, the haunt of the spirit or goblin Button-cap, whose appearance on a cannon heralded any commotion, so he was probably visible on these occasions, as will be evident. At the Castle the Mayor elect was sworn into office, after which, says M'Skimmin, "a bull was fastened to a ring in the market-place, and baited with bull-dogs. In the evening the Mayor gave a banquet, known as the Mayor's Feast, to various members of the Corporation. It was a matter of great pomp up to the nineteenth contury. Baiting ccased," he says, "about I 804," but eight years later one "Arthur Chichester gave a bull to be baited, in order to revive that humane sport "and the Mayor had to disperse the mob. After the bullbaiting was stopped an animal was still killed on that day, and the flesh given to the poor, each claimant receiving also half a loaf. According to the Statutes of Knockfergus "if anie man doe bye anje horse or beefe after sone sett untill the next daye at 6 of the clock in the morninge, to forfeyte 7s. 8d. to the maior." Moreover, the Mayor as Clerk of the Market had the tongues of all bullocks or cows killed on Friday whose flesh was sold in the market on Saturday.

"In Waterford and other towns," says the author of Sketches in Ireland Sixty Years Ago, "on the election of every mayor, he was surrounded by a mob, who shouted out, 'a rope, a rope, a rope!' and the new mayor never failed to grant their demands. A rope two inches in diameter, with a competent leather collar and buckle, had been previously prepared, and was then delivered to the claimants, who bore it away in triumph, and deposited it in the city jail-yard, to remain there till wanted. We have an extract before us from the old corporation books of Waterford dated I814, October, in which month the slaughtering season commenced: 'Ordered, that a bullrope be provided at the charge of the city revenue.' Under this sanction the populace assumed the authority of seizing all the bulls, and driving them to the bull-ring to be baited 
before they were killed. The place for baiting them was an open space outside the city gate, called Ballybricken. It was surrounded with houses, from which spectators looked on, as at a Spanish bull-fight. In the centre was the ring through which the rope was passed. It was surmounted by a pole, bearing a large copper bull on a vane. In 1798 , when bull baits were prohibited, this apparatus was removed, and the sport discontinued; but prior to that it was followed with the greatest enthusiasm; and it was not unusual to see eighteen or twenty of these animals baited during the season.... When, on occasions, a rope was refused by a refractory mayor, or a new one wils required, the bull was driven through the streets of the town, and sometimes even into his worship's shop or hall, as a hint of what was wanted, and the civic authoritics were often called out with the military to repress the riots that ensued."

A special law was passed in Dublin during George III.'s reign forbidding bulls to be seized on the way to or from market. Dublin bulls were baited in the Corn-market, and you may remember my previous account of the Mayor of the Bull-ring, who was guardian of the bachelors, and kissed the brides at the aforesaid ring. The slang song, "Lord Altham's Bull," describes a bull drive as mentioned above, and tells how:

"We drove de bull down Corn-market As all the world might segee."

There is reference to this also in another slang song dealing with the theft of a May Bush by the Liberty boys, in consequence whereof it was threatened that a bull should be driven down their streets :

"For de loss of our bush, revenge we will get

Ri rigidi, ri ri dam dee,

In the slaughtering season we'll tip 'em a sweat,

Rigidi di do dee. 
We'll wallop a mosey down Mead-Street in tune And we won't leave a weaver alive in de Coombe But we'll rip up his tripe bag, and burn his loom Ri rigidi, di do, dee!"

Fights between the different city companies were only to be expected in a land where faction fights may be con. sidered calendar customs. Smith, in his History of Cork, mentions "great riots between the weavers and butchers at the fair of this city " in the beginning of June. Thistelton Dyer, of course, quotes Fitzgerald's account of the Midsummer Day march of the Limerick tradesmen, with "their merry-men" who, like those with the Claddagh fishermen's Midsummer procession, "played a thousand antic tricks." 'But the finale was not so peaceful as in Galway, for "the day generally ended in a terrible fight between the Garryowen and Thomond Gate boys (the tradesmen of the north and south suburbs)." A Limerick ballad gives the tale of the "Battle of the Mayor's Stone."

"We are bold Limerick Clothiers, we'll have you for to know That we must bear the sway wherever we shall go;

Though Vulcan with his weapons had sworn he'd kill the Weavers,

Assisted by the Carpenters, and by the Masons too-

There were Tinkers, Bricklayers, Glaziers with Stone Cutters and Braziers,

All joined against the Weavers, but all it would not do.

For as we sat merry boozing, the plot it was concluding

Which spread a vast confusion outside of Thomond Gate, But these dogs they were so footy, in as they had no booty,

We taught them then their duty and made them soon retreat.

For when first they did attack us with adzes keen and axcs,

They stood as if already fixed our Clothiers to destroy:

But soon we did attack them, and nobly we did whack them,

To our great satisfaction we worked them sore annoy." 
There are many verses descriptive of the fortunes of the fight, and one tells how "their daughters, wives and elders like poisoned Salamanders" joined in the fray! The finale is typical:

"Now Clothiers sit ye merry, drink brandy, wine, and sherry, Malaga and canary, fill bumper, do not spare !"

At Drogheda again we find annual battle waged between north and south, the part of the city on opposite sides of the Boyne. This took place on Shrove Tuesday. One side was led by the "Mayor of Flea Lane," an obscure lane in the suburbs behind Millmount (which is an earthwork " connected by a raised causeway or bridge" with a bank abutting on the Boyne, says the Dublin Penny Fournal). The "Mayor of Flea Lane" crossed the bridge over the river and entered the northern part of the town "mounted on an ass, in mock procession, attended by his sheriffs, bailiffs, and other officers, all fantastically dressed with straw, and each bearing the insignia of his dignity, together with several ragamuftins disguised in petticoats and masks and armed with blown bladders on poles " to clear a way. The cavalcade was " proceeded by a 'bough" or garland," and music. The principal streets were traversed and contributions levied. Meanwhile another party entered by Lawrence's Gate, "the Mayor of the Chord" and his followers "generally dressed in cast-soldiers' clothes." They marched "in another direction until evening, or they conceive they have enough collected, when they meet and after a mock encounter between the 'bladdermen' . . . all adjourn to the 'chord field ' outside Lawrence's Gate and spend the evening in mirth and jollity."

The "Mayor of the Chord" and the "chord field" certainly suggest the Mayor of the Bull-ring and "A rope, a rope !" But so far as the sham fight is concerned history gives an explanation, without which guidance the folklorist might stray to many a false prenise. Drogheda originally 


\section{Folklore and History in Jreland.}

was not one borough but two, Drogheda in Louth, and Drogheda in Meath, each with its charters and gilds, till Henry IV. united them and made Drogheda " a "corporate' county." The story goes that one Father Philip Bennett in order to stop the dissensions between north and south which led to frequent fighting and often to bloodshed, "invited both sides to hear a sermon on Ps. ixxxiii." During the course of it he "thrice asked the congregation with energy 'will ye be united in the body of Christ?' Alderman William Symcock answered in the name of all, 'We will'-they then feasted at the convent of St. Mary Magdalene and by the advice of Father Bennett sent a petition to the King, who granted a charter on December 15th, following, 'uniting the two sides into one Town of Drogheda, and under one mayor, and forming it into a special county." "

Here then is History explaining Folklore. Reciprocally may we not find Folklore illuminating some dark passages in Irish history? At least Folklore may have a message and a lesson as well for the English, who appear incapable of remembering the past, as for the Irish, who refuse to look anywhere else. These matters of local officials decked out in brief authority may seem trivial and without im. portance, yet they are links in the chain of national life, links at present rather loose and dislocated I fear me. But they bear witness to the introduction of a measure of organisation and consolidation for which scant credit is given to England. The fact that so many of the customs hinged upon, or resulted in fightings, is no surprising feature in the municipal history of a land where dissensions have been rife from time immemorial. In common with the folk who introduced them many of the transplanted customs have been submerged-some, as I may show at another time, survive, attached to quite other observances than were theirs originally. But for the most part the engrafted customs have proved ephemeral. They are the fashions 
3o4 Folklore and Historys in Ireland.

of the folk, the outcome of the thought and exvents of the moment, and like all fashions fugitive. They are mainly corncerned with mutable matters of form and ceremony, but of no vital import, while the indigenous growth survives in the more private but more essential acts and beliefs. The persistencies are to be found connected with such immutable matters as life and death, birth and marriage.

D. H. Moutray Read. 